\title{
COVID-19 and its impact on the control of Aedes (Stegomyia) aegypti mosquito and epidemiological surveillance of arbovirus infections
}

\author{
Jorge Castañeda-Gómez, ${ }^{1}$ Cassandra González-Acosta, ${ }^{2}$ Jocelyn L. Jaime-Rodríguez, ${ }^{2}$ \\ Alejandro Villegas-Trejo ${ }^{3}$ and Miguel Moreno-García ${ }^{2,4 *}$ \\ ${ }^{1}$ State Vector Program, Servicios de Salud de Sonora, Hermosillo, Sonora; ${ }^{2}$ Coordination of Vector-borne Diseases and Zoonosis, Servicios de \\ Salud de Morelos, Cuernavaca, Morelos; ${ }^{3}$ Asesoría y Capacitación en Salud Pública y Enfermedades Transmitidas por Vectores, S.A. de C.V., \\ Cuernavaca, Morelos; ' $E$ Entomological Research and Bioassay Unit, Servicios de Salud de Morelos, Panchimalco Regional Vector Control Center, \\ Jojutla, Morelos. México
}

\begin{abstract}
In American countries, simultaneously with the coronavirus disease 2019 (COVID-19) pandemic, epidemics caused by different arboviruses (dengue, chikungunya and Zika viruses) are occurring. In Mexico, several of the strategies to control the Aedes aegypti mosquito, which transmits arboviruses, involve the interaction of health personnel with the community. Due to the COVID-19 pandemic, social distancing and home confinement measures have been implemented. To obey these measures and avoid the risk of severe acute respiratory syndrome coronavirus 2 (SARS-CoV-2) transmission, the National Center for Preventive Programs and Disease Control (CENAPRECE) has presented the vector control strategy in the scenario of simultaneous dengue and COVID-19 transmission in Mexico. In this work, we mention the routine comprehensive mosquito control measures and describe the adaptations that have been made. Furthermore, we discuss the relevance of medical personnel training and supervision, especially focusing on the similarity of symptoms between both pathologies.
\end{abstract}

KEY WORDS: Arboviruses. COVID-19. Comprehensive vector management. Aedes aegypti.

\section{COVID-19 y su impacto en el control del mosquito Aedes (Stegomyia) aegypti y la vigilancia epidemiológica de infecciones por arbovirus}

\section{Resumen}

En países americanos, simultáneas a la pandemia de enfermedad por coronavirus 2019 (COVID-19) se están dando epidemias ocasionadas por diferentes arbovirus (del dengue, chikunguña y virus del Zika). En México, varias de las estrategias para control del mosquito Aedes aegypti, transmisor de arbovirus, involucran la interacción del personal salubrista y los moradores. Debido a la pandemia de COVID-19 se han implementado medidas de distanciamiento social y resguardo domiciliario. Para respetar estas medidas y evitar riesgo de contagio por coronavirus 2 del síndrome respiratorio agudo grave (SARS-CoV-2), el Centro Nacional de Programas Preventivos y Control de Enfermedades (CENAPRECE) ha presentado la estrategia de control de vectores en el escenario de transmisión simultánea por dengue y COVID-19 en México. En este trabajo mencionamos las medidas habituales de manejo integral de mosquito y mencionamos las adaptaciones realizadas. De igual forma, discutimos la relevancia de la capacitación y la supervisión al personal médico, esto debido a la similitud entre la sintomatología entre ambas patologías.

PALABRAS CLAVE: Arbovirus. COVID-19. Manejo integrado de vectores. Aedes aegypti. 


\section{Introduction}

Coronavirus disease 2019 (COVID-19), caused by severe acute respiratory syndrome coronavirus 2 (SARS-CoV-2), had its origin in Wuhan, China, on December 2019, and spread in early 2020 across Europe, Oceania and the Middle East, to finally reach Africa. ${ }^{1}$ In the region of the Americas, the first case was reported in the US (January 23, 2020); ${ }^{2}$ subsequently, cases were detected in Canada and Latin American countries, with the first confirmed case of COVID-19 being recorded in Mexico on February 29, 2020. ${ }^{3}$ In March 2020, COVID-19 was declared a pandemic, with the negative impact on the health of the world population being evident. ${ }^{4}$

By the date this article is written (June 27, 2020), 54 American countries/territories have a total of 4,923,661 confirmed cases and 243,896 deaths. ${ }^{5}$ Given the severity of the pandemic, and due to the lack of vaccines or effective treatment, American governments have been implementing sanitary measures, with social distancing, home isolation and preventive measures such as correct hand washing being the main strategies to minimize viral transmission. ${ }^{6}$ This, in order not to collapse the health systems and decrease the incidence and lethality of infection. ${ }^{5,7}$ However, a side effect of the COVID-19 pandemic is the impact on other health programs, such as programs for the prevention and control of vector-borne infectious diseases (VBDs) (e.g. dengue, chikungunya, Zika, malaria, Chagas). ${ }^{8}$

In American countries located in tropical areas, along with the COVID-19 pandemic, VBD epidemics caused by different arboviruses (dengue, chikungunya and Zika) are simultaneously occurring. ${ }^{9-11}$ Specifically, the disease caused by dengue virus (DENV), transmitted by the Aedes aegypti mosquito, which currently is the main viral disease transmitted by arthropods. ${ }^{12}$ This situation is concerning in some Central American countries such as Costa Rica and Panama, since in the first half of the year 2020 they recorded a larger number of cases and higher incidence with regard to the same semester of previous year (Table 1).$^{13}$ In addition to this, the World Health Organization estimates that each year there are between 50 and 100 million new cases of people infected by DENV in the world, as well as around 500,000 people with complications that require hospitalization, with $2.5 \%$ dying. ${ }^{14,15}$ Particularly, in the first semester of 2020, Mexico has recorded a larger number of cases and higher incidence with regard to the same semester of 2019 (Table 1). ${ }^{12,13}$ This, coupled with the COVID-19 pandemic, requires for the comprehensive vector management (CVM) strategies to be adapted in order to limit the negative impact of arboviruses on the vulnerable human population. ${ }^{16,17}$

\section{Control of Aedes aegypti, vector of dengue, chikungunya and Zika}

In Mexico, strategies to fight Aedes aegypti are based on monitoring for its presence and population density by means of ovitraps, ${ }^{18}$ entomological studies ${ }^{19}$ and entomovirological surveillance (collection of adult mosquitoes for viral particles detection. ${ }^{20}$ This allows establishing areas of risk for focusing health promotion activities with workshops and awareness-raising of the population, about physical and chemical control of the mosquito early phases (larvae), ${ }^{21}$ in a comprehensive way with junk-discarding actions (which consist of elimination of useless things that may become sites for oviposition and rearing of larvae indoors and outdoors). For probable and confirmed cases of dengue, residual insecticide spraying is applied indoors, as long as residents allow access during the contingency phase due to COVID-19. ${ }^{22,23}$ In the event of an arbovirus outbreak, as the last option for control, insecticides are applied on a large scale by misting with heavy vehicle-mounted equipment or personal thermal machines (thermal fogging). ${ }^{24-26}$

The described activities are carried out by health workers assigned to the health programs of each one of the 32 States, who carry them out inside and outside the houses, but these activities were restricted as a result of phase 3 of COVID-19 health contingency (Fig. 1). ${ }^{16}$ Before COVID-19, health personnel actively encouraged the participation of residents so that later they could be able to eliminate mosquito breeding sites and discard junk from their homes. However, owing to the strategy of home isolation and social distancing due to COVID-19, the Vector-borne Diseases Program of the National Center of Preventive Programs and Disease Control (CENAPRECE Centro Nacional de Programas Preventivos y Control de Enfermedades) of the Ministry of Health of Mexico adapted these activities according to the pandemic phase (Table 2). ${ }^{27}$ These adaptations limit all 
Table 1. Panorama of dengue disease in Mexico, Central America and the Americas corresponding to the months of January, February, March, April, May and June (epidemiological weeks 1 to 27)

\begin{tabular}{|c|c|c|c|c|c|c|c|c|}
\hline \multirow[t]{2}{*}{ Country/region } & \multicolumn{4}{|c|}{2019} & \multicolumn{4}{|c|}{2020} \\
\hline & Cases & Incidence* & Severe dengue & Deaths & Cases & Incidence* & Severe dengue & Deaths \\
\hline Mexico & 29,910 & 22.87 & 336 & 20 & 30,444 & 23.28 & 359 & 11 \\
\hline El Salvador & 6,609 & 103.07 & 24 & 0 & 3,306 & 51.56 & 4 & 0 \\
\hline Costa Rica & 2,425 & 48.96 & 0 & 0 & 3,729 & 75.29 & 8 & 0 \\
\hline Nicaragua & 43,994 & 699.98 & 194 & 6 & 25,882 & 411.81 & 25 & 0 \\
\hline Panama & 1,913 & 45.95 & 4 & 2 & 3,304 & 79.37 & 11 & 3 \\
\hline Belize & 903 & 236.39 & 0 & 0 & $473^{+}$ & $123.82^{\dagger}$ & $0^{+}$ & $0^{+}$ \\
\hline Guatemala & 8,050 & 46.68 & 61 & 31 & 3,899 & 22.61 & 7 & 5 \\
\hline Honduras & 30,099 & 328.66 & 6,795 & 51 & 15,372 & 167.85 & 1,265 & 9 \\
\hline The Americas & $2,172,766$ & 222.57 & 9,682 & 906 & $1,724,175$ & 176.61 & 3,677 & 613 \\
\hline
\end{tabular}

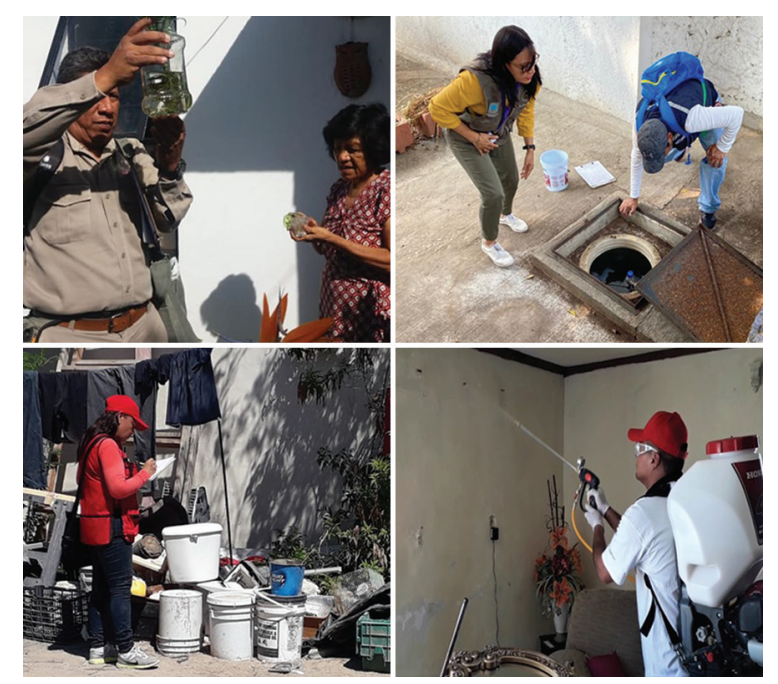

Figure 1. Vector control comprehensive actions carried out by Mexico's health workers.

intra-domiciliary activities that are carried out in the dengue prevention and control program, in order to respect social distancing for the protection of residents and health workers, and thus avoid a potential risk of SARS-CoV-2 transmission. However, when said CVM activities require to be carried out, personal protection measures should be implemented, coupled with a healthy distance from the resident (1.5 meters), and shall be reinforced with continuous hand washing and handshake avoidance. ${ }^{28}$

\section{Social communication and health promotion}

Raising public awareness is and will continue to be the most important strategy to combat both epidemics. Therefore, it is necessary to reinforce the dissemination of strategic campaigns focused on controlling and eliminating mosquito breeding sites, as well as on dengue and COVID-19 characteristic symptoms (Table 3), ${ }^{15,29-31}$ with the use of television spaces, social networks, radio, vehicle-mounted loudspeakers being recommended, for which active participation in social communication and health promotion is required. ${ }^{32}$ This is also intended to prevent the population from becoming reluctant to the different activities carried out by the health worker for vector control, which help to avoid an increase in mosquito population density (and, consequently, to reduce the probability of arbovirus infection).

\section{Problems in vector-borne diseases epidemiological surveillance}

In Mexico, epidemiological information is collected and integrated within the National Epidemiological Surveillance System (SINAVE - Sistema Nacional de Vigilancia Epidemiológica) and, in turn, it is monitored through different programs of the General Directorate of Epidemiology, a federal regulatory body of SINAVE, 
Table 2. Proposal of activities for the control of Aedes aegypti in the face of the coronavirus disease 2019 (COVID-19) pandemic according to the phase (numbers of COVID-19 cases)

\begin{tabular}{|c|c|c|c|}
\hline Activity & Phase 1 (tens of cases) & Phase 2 (hundreds of cases) & Phase 3 (thousands of cases) \\
\hline $\begin{array}{l}\text { Entomological } \\
\text { surveillance with } \\
\text { ovitraps }\end{array}$ & $\begin{array}{l}\text { Normal activity, generation of } \\
\text { report on readings } \\
\text { Personal protection with face } \\
\text { mask }\end{array}$ & $\begin{array}{l}\text { Normal activity in dengue risk } \\
\text { zones, generation of report on } \\
\text { readings } \\
\text { Personal protection with face mask }\end{array}$ & $\begin{array}{l}\text { Activity limited to dengue high risk zones, } \\
\text { generation of report on readings for decision } \\
\text { making } \\
\text { Personal protection with face mask }\end{array}$ \\
\hline $\begin{array}{l}\text { Entomological } \\
\text { investigations }\end{array}$ & $\begin{array}{l}\text { Normal activity, generation of } \\
\text { report on readings } \\
\text { Personal protection with face } \\
\text { mask }\end{array}$ & $\begin{array}{l}\text { Activity limited to zones with } \\
\text { arbovirus outbreaks Personal } \\
\text { protection with face mask }\end{array}$ & Suspended activity \\
\hline $\begin{array}{l}\text { Entomovirological } \\
\text { surveillance }\end{array}$ & $\begin{array}{l}\text { Normal activity, generation of } \\
\text { report on readings } \\
\text { Personal protection with face } \\
\text { mask }\end{array}$ & $\begin{array}{l}\text { Activity restricted to homes without } \\
\text { probable or confirmed cases of } \\
\text { dengue } \\
\text { Personal protection with face mask }\end{array}$ & Suspended activity \\
\hline Larval control & $\begin{array}{l}\text { Normal activity, generation of } \\
\text { report on readings } \\
\text { Personal protection with face } \\
\text { mask }\end{array}$ & $\begin{array}{l}\text { Activity restricted to homes without } \\
\text { probable or confirmed cases of } \\
\text { dengue } \\
\text { Personal protection with face mask }\end{array}$ & Suspended activity \\
\hline $\begin{array}{l}\text { Indoor spraying for } \\
\text { probable/confirmed } \\
\text { cases of dengue. }\end{array}$ & $\begin{array}{l}\text { Normal activity } \\
\text { Personal protection with } \\
\text { gloves, googles, face mask } \\
\text { and face shield }\end{array}$ & $\begin{array}{l}\text { Activity limited to thermal fogging } \\
\text { inside the home and around the } \\
\text { block of the dengue case, and } \\
\text { fogging with heavy duty ULV fogger } \\
\text { Personal protection with overalls, } \\
\text { gloves, goggles, face mask and } \\
\text { face shield }\end{array}$ & $\begin{array}{l}\text { Thermal fogging activity inside the home of } \\
\text { the dengue case; if confirmed, the area is } \\
\text { extended to } 9 \text { blocks around } \\
\text { Personal protection with overalls, gloves, } \\
\text { goggles, face mask and face shield }\end{array}$ \\
\hline $\begin{array}{l}\text { Space fogging } \\
\text { (heavy duty ULV } \\
\text { fogger) }\end{array}$ & $\begin{array}{l}\text { Normal activity } \\
\text { Personal protection with } \\
\text { overalls, face mask, gloves } \\
\text { and goggles }\end{array}$ & $\begin{array}{l}\text { Activity to reinforce with higher } \\
\text { coverage in areas with probable } \\
\text { cases } \\
\text { Personal protection with overalls, } \\
\text { face mask, gloves and goggles }\end{array}$ & $\begin{array}{l}\text { Attention to localities with historical } \\
\text { epidemiological risk, weekly fogging for four } \\
\text { weeks to the entire transmission area. } \\
\text { Attention with a fogging cycle after a massive } \\
\text { junk disposal campaign in at-risk localities. } \\
\text { Personal protection with overalls, gloves, } \\
\text { goggles, face mask and face shield }\end{array}$ \\
\hline Thermal fogging & $\begin{array}{l}\text { Normal activity } \\
\text { Personal protection with } \\
\text { gloves, goggles, face mask } \\
\text { and face shield }\end{array}$ & $\begin{array}{l}\text { Activity targeting the house and } \\
\text { block of probable/confirmed } \\
\text { dengue case } \\
\text { Personal protection with overalls, } \\
\text { gloves, goggles, face mask, face } \\
\text { shield }\end{array}$ & $\begin{array}{l}\text { Attention to blocks with entomological risk } \\
\text { (ovitraps with a larger number of eggs), } \\
\text { attention by probable case according to the } \\
\text { case classification } \\
\text { In areas where the vehicle with heavy } \\
\text { equipment does not have access, personal } \\
\text { protection with overalls, gloves, goggles, face } \\
\text { mask and face shield }\end{array}$ \\
\hline
\end{tabular}

ULV = ultra-low volume.

Based on and adapted from Centro Nacional de Programas Preventivos y Control de Enfermedades, $2020{ }^{27}$

which, together with the state and jurisdictional counterparts of each one of these programs, analyze, evaluate and disseminate said information in order to generate strategies and actions for the management and control of diseases that represent relevant risks to public health. Epidemiological information comes from primary and secondary care institutions that belong to the National Health System of the entire country $\left(20,005\right.$ units). ${ }^{33}$

For arboviruses surveillance, first-contact doctors of the different health institutions are in charge of notifying probable cases to the corresponding health jurisdiction, which, in turn, notifies at the state level (NOM-017-SSA2-2012 standard, for epidemiological surveillance). ${ }^{34}$ This is how VBD prevention and control strategies go hand in hand with epidemiological surveillance, since with continuous notification of cases (on a daily basis), Health Services of each State focus, plan and stratify different actions for the control of mosquitoes at their region.

During the COVID-19 pandemic, training and supervision of medical personnel are of vital importance for 
Table 3. Symptoms caused by the dengue virus and SARS-CoV-2

\begin{tabular}{l|l|l}
\hline $\begin{array}{l}\text { Non-severe dengue with } \\
\text { no signs of alarm }\end{array}$ & $\begin{array}{l}\text { Non-severe dengue with } \\
\text { signs of alarm }\end{array}$ & Severe dengue \\
\hline - Fiebre & - Intense and continuous & - Shortness of breath \\
- Headache & abdominal pain & - Organ failure (liver, kidney, etc.) \\
- Retro-orbital pain & - Persistent vomiting & - Intense abdominal pain \\
- Muscle pain & - Build-up of fluid & - Severe bleeding \\
- Joint pain & - Gums and nose bleeding & - Accelerated respiratory and heart rate \\
- Bone pain & - Weakness and somnolence & - Presence of blood in vomit and stools \\
- Nausea & - Low blood pressure and & - Cold extremities \\
- Vomiting & sensation of dizziness & - Weak or undetectable pulse \\
- Lymph node enlargement & - Irritability or restlessness & - Build-up of fluid \\
- Rash & &
\end{tabular}

\section{COVID-19}

Most common symptoms:

- Fever

- Dry cough

- Headache

- Tiredness and/or muscle pain

Less frequent symptoms:

- Nasal congestion and/or discharge

- Conjunctivitis

- Sore throat

- Diarrhea

- Loss of taste and/or smell

- Rashes

- Change of color in fingers or toes

Severe symptoms:

- Shortness of breath

- Chest pain

- Speech disorder

SARS-CoV-2 = severe acute respiratory syndrome coronavirus 2; COVID-19 = coronavirus disease 2019.

Adapted from World Health Organization, 2020,15,29 Centers for Disease Control and Prevention, 2019,30 Pan American Health Organization. ${ }^{31}$

strengthening epidemiological surveillance and arboviruses correct clinical management, since if these activities are deficient in endemic regions, it could result in an epidemiological silence that would prevent accurate data from being obtained. Similarly, an incorrect classification and treatment of patients could occur due to the existence of similar symptoms between dengue and COVID-19 (Table 3), ${ }^{35}$ with greater complications and even deaths in patients with this VBD being generated.

In addition to fever, shared observable symptoms include: thrombocytopenia (platelet count decrease), ${ }^{35}$ petechiae (skin vascular effusions), ${ }^{36}$ morbilliform exanthem (rash), ${ }^{37}$ headache, myalgia (muscle pain), and arthralgia (joint pain). ${ }^{38}$ There is scientific evidence that SARS-CoV-2 infection can generate false positive results in diagnostic serological tests for dengue ${ }^{35}$ therefore, in case of possible confusion, to avoid complications in the patient, using a RT-PCR test for both diseases and avoiding diagnosis with serological test is recommended, and emphasis is made on the warning signs of both pathologies, i.e., intense and continuous abdominal pain in dengue and dyspnea in COVID-19. These symptomatic characteristics are relevant for detecting, classifying and clinically treating both diseases, in addition to the fact that, due to the characteristics in the form of transmission, a mortality decrease is expected owing to the organization and management of patients at hospital care centers.

\section{Conclusion}

For tropical countries, including Mexico, the rainy season starts at the end of May, whereby the epidemic stage of dengue and other VBDs also begins. It is during this period that a rebound in COVID-19 cases is also expected in several regions of the country that are highly endemic for dengue. Countries' health systems face the challenge of combining usual health programs with strategies to combat the COVID-19 pandemic, and the study and management of patients will therefore be crucial to reduce mortality of both diseases.

COVID-19 natural history is still unknown, and although information is being rapidly generated, it is uncertain when the high-transmission stage will end. For this reason, it is necessary to urgently organize and synchronize the actions to control the vector and SARS-CoV-2 that do not require contact between citizens and health workers, such as space spraying and thermal fogging, in order to reduce the density of the mosquito in as much as possible. Furthermore, for an adequate impact and to establish risk zones with the highest accuracy, reinforcement of epidemiological surveillance and clinical management of patients is required in order to obtain valuable information and decrease mortality. 
All sources of information are public in nature and have the sole purpose of providing specific information. The conclusion represents the opinion of the authors and not of the affiliation institutions.

\section{Conflict of interests}

The authors declare that they have no conflicts of interest.

\section{Funding}

This document had no funding source, either public or private.

\section{Ethical disclosures}

Protection of human and animal subjects. The authors declare that no experiments were performed on humans or animals for this research.

Confidentiality of data. The authors declare that they have followed the protocols of their work center on the publication of patient data.

Right to privacy and informed consent. The authors declare that no patient data appear in this article.

\section{References}

1. Coronavirus disease 2019 (COVID-19). Situation report-26, 15 February 2020 [Internet]. Geneva, Switzerland: World Health Organization; February 15, 2020 [accessed: June 27, 2020]. Available at: https://www. who.int/docs/default-source/coronaviruse/situation-reports/20200215-sitrep-26-covid-19.pdf?sfvrsn=a4cc6787_2

2. Novel Coronavirus (2019-nCoV). Situation report-3, 23 January 2020 [Internet]. Geneva, Switzerland: World Health Organization; January 23, 2020 [accessed: June 20, 2020]. Available at: https://www.who.int/docs/ default-source/coronaviruse/situation-reports/20200123-sitrep-3-2019ncov.pdf?sfvrsn=d6d23643 8

3. Coronavirus disease 2019 (COVID-19). Situation report-40, 29 February 2020 [Internet]. Geneva, Switzerland: World Health Organization; February 29, 2020 [accessed: June 20, 2020]. Available at: https://www. who.int/docs/default-source/coronaviruse/situation-reports/20200229-sitrep-40-covid-19.pdf?sfvrsn=849d0665_2

4. Alocución de apertura del Director General de la OMS en la rueda de prensa sobre la COVID-19 celebrada el 11 de marzo de 2020 [Internet]. Geneva, Switzerland: Organización Mundial de la Salud; March 11, 2020 [accessed: June 23, 2020]. Available at: https://www.who.int/es/dg/speeches/detail/who-director-general-s-opening-remarks-at-the-media-briefing-on-covid-19---11-march-2020

5. Coronavirus disease (COVID-19). Situation report-159, 27 June 2020 [Internet]. Geneva, Switzerland: World Health Organization; June 27, 2020 [accessed: June 27, 2020]. Available at: https://www.who.int/docs/default-source/coronaviruse/situation-reports/20200627-covid-19-sitrep-159.pdf?sfvrsn=93e027f6_2

6. Pass the message: five steps to kicking out coronavirus, 23 March 2020 [Internet]. Geneva, Switzerland: World Health Organization; March 23, 2020 [accessed: June 22 2020]. Available at: https://www.who.int/news-room/ detail/23-03-2020-pass-the-message-five-steps-to-kicking-out-coronavirus

7. Coronavirus Resource Center. Johns Hopkins University and Medicine [Internet]. Johns Hopkins University and Medicine; 2020 [accessed: June 25 2020]. Available at: https://coronavirus.jhu.edu/map.html

8. La OMS publica directrices para ayudar a los países a mantener los servicios sanitarios esenciales durante la pandemia de COVID-19 [Internet]. Geneva, Switzerland: World Health Organization; 2020 [accessed: June 26, 2020]. Available at: https://www.who.int/es/news-room/detai1/30-03-2020-who-releases-guidelines-to-help-countries-maintain-essential-health-services-during-the-covid-19-pandemic
9. Wenham C, Lotta G, Pimenta D. Mosquitoes and COVID-19 are a ticking time bomb for Latin America [Internet]. The London School of Economics and Political Science; March 31, 2020 [accessed: June 19, 2020]. Available at: https://blogs.Ise.ac.uk/latamcaribbean/2020/03/31/mosquitoesand-covid-19-are-a-ticking-time-bomb-for-latin-america

10. Lago M. América Latina puede convertirse en la mayor víctima del COVID-19 [Internet]. The New York Times; March 19, 2020 [accessed: June 15, 2020]. Available at: https://www.nytimes.com/es/2020/03/19/ espanol/opinion/coronavirus-america-latina-gobiernos.html

11. Boris M. Por qué América Latina está registrando "la mayor epidemia de dengue de su historia" [Internet]. BBC news Mundo; February 13, 2020 [accessed: June 19, 2020]. Available at: https://www.bbc.com/mundo/ noticias-51496280

12. Actualización epidemiológica: Dengue, 23 de marzo de 2020 [Internet]. Washington, D.C.: Organización Panamericana de la Salud; March 23, 2020 [accessed: June 24, 2020]. Available at: https://www.paho.org/es/ documentos/actualizacion-epidemiologica-dengue-23-marzo-2020

13. Casos Dengue [Internet]. Washington, D.C.: Organización Panamericana de la Salud, PLISA Plataforma de Información en Salud para las Américas [accessed: June 26, 2020]. Available at: https://www.paho.org/data/ index.php/es/temas/indicadores-dengue/dengue-nacional/9-dengue-pais-ano.html

14. Dengue [Internet]. Washington, D.C.: Pan American Health Organization [accessed: June 24, 2020]. Available at: https://www.paho.org/en/topics/ dengue

15. Dengue and severe dengue [Internet]. Geneva, Switzerland: World Health Organization; June 23, 2020 [accessed: June 26, 2020]. Available at: https://www.who.int/news-room/fact-sheets/detail/dengue-and-severe-dengue

16. Handbook for integrated vector management in the Americas. 2019 [Internet]. Washington, D.C.: Pan American Health Organization; 2019 [accessed: June 21, 2020]. Available at: https://iris.paho.org/bitstream/ handle/10665.2/51759/Manejo \%20Integrado_ENG_FINAL3.pdf?sequence $=1$ and is Allowed $=y$

17. Malaria and the COVID-19 pandemic. 8 June 2020 [Internet]. Geneva, Switzerland: World Health Organization; June 8, 2020 [accessed: June 27, 2020]. Available at: https://www.who.int/news-room/q-a-detail/malaria-and-the-covid-19-pandemic

18. Guía Metodológica para la Vigilancia Entomológica con Ovitrampas. 2018 [Internet]. Mexico City, Mexico: Centro Nacional de Programas Preventivos y Control de Enfermedades; 2018 [accessed: June 22, 2020]. Available at: https://www.gob.mx/cms/uploads/attachment/ file/354685/Guia_Metodologica_para_Vigilancia_Entomologica_con_ Ovitrampas.pdf

19. Guía Metodológica para Estudios Entomológicos en Fase Larvaria y Pupal. 2018 [Internet]. Mexico City, Mexico: Centro Nacional de Programas Preventivos y Control de Enfermedades; 2018 [accessed: June 22, 2020]. Available at: https://www.gob.mx/cms/uploads/attachment/ file/399677/Guia_Metodolo_gica_para_Estudios_Entomolo_gicos_en_ Fase_larvaria_y_Pupal.pdf

20. Guía Metodológica para la Vigilancia Entomovirológica. 2018 [Internet]. Mexico City, Mexico: Centro Nacional de Programas Preventivos y Control de Enfermedades; 2018 [accessed: June 23, 2020]. Available at: https://www.gob.mx/cms/uploads/attachment/file/354682/Guia_Metodol_ gica_para_la_Vigilancia_Entomovirologica.pdf

21. Guía Metodológica para las Acciones de Control Larvario. 2018 [Internet]. Mexico City, Mexico: Centro Nacional de Programas Preventivos y Control de Enfermedades; 2018 [accessed: June 23 2020]. Available at: https://www.gob.mx/cms/uploads/attachment/file/355418/Guia_Metodol_ gica_para_las_Acciones_de_Control_Larvario.pdf

22. Guía Metodológica para el Rociado Domiciliario. 2018 [Internet]. Mexico City, Mexico: Centro Nacional de Programas Preventivos y Control de Enfermedades; 2018 [accessed: June 22, 2020]. Available at: https:// www.gob.mx/cms/uploads/attachment/file/354678/Gu_a_Metodol_gica_ para_el_Rociado_Domiciliario.pdf

23. Indoor residual spraying, an operational manual for indoor residual spraying (IRS) for malaria transmission control and elimination. 2015 [Internet]. Geneva, Switzerland: World Health Organization; 2015 [accessed: June 19, 2020]. Available at: https://apps.who.int/iris/bitstream/handle/10665/177242/9789241508940_eng.pdf?sequence=1 and isAllowe$\mathrm{d}=\mathrm{y}$

24. Guía de Nebulización (Rociado Espacial) para la Aplicación de Insecticida a Ultra Bajo Volumen (UBV) con Equipo Pesado. 2018 [Internet] Mexico City, Mexico: Centro Nacional de Programas Preventivos y Control de Enfermedades; 2018 [accessed: June 20, 2020]. Available at: https://www.gob.mx/cms/uploads/attachment/file/354684/Guia_Metodologica_para_Nebulizacion_Espacial_UBV.pdf

25. Guía de Nebulización Térmica para la Aplicación de Adulticida con Equipo Portátil. 2018 [Internet]. Mexico City, Mexico: Centro Nacional de Programas Preventivos y Control de Enfermedades; 2018 [accessed: June 21, 2020]. Available at: https://www.gob.mx/cms/uploads/ attachment/file/354680/Guia_Metodologica_para_la_Nebulizacion_ Termica.pdf 
26. Space spray application for insecticides for vector and public health pest control, a practitioner's guide. 2020 [Internet]. Geneva, Switzerland: World Health Organization; 2020 [accessed: June 23, 2020]. Available at: https://apps.who.int/iris/bitstream/handle/10665/68057/ WHO_CDS_WHOPES_GCDPP_2003.5.pdf?sequence $=1$ and isAllowed $=\mathrm{y}$

27. Estrategia de control de vectores en el escenario de transmisión simultánea Dengue y COVID-19 en México. 2020 [Internet]. Mexico City, Mexico: Centro Nacional de Programas Preventivos y Control de Enfermedades; 2020 [accessed: June 18, 2020]. Available at: https://www.gob. $\mathrm{mx} / \mathrm{cms} /$ uploads/attachment/file/551912/Estrategia_Control_Vectores_ COVID-19 Mexico.pdf

28. Coronavirus (COVID-19) Comunicado técnico diario. 2020 [Internet] Mexico City, Mexico: Secretaría de Salud; 2020 [accessed: June 24, 2020]. Available at: https://www.gob.mx/salud/documentos/coronavirus-covid-19-comunicado-tecnico-diario-238449

29. Preguntas y respuestas sobre la enfermedad por coronavirus (COVID-19) [Internet]. Geneva, Switzerland: World Health Organization; 2020 [accessed: June 27, 2020]. Available at: https://www.who.int/es/ e mergencies/diseases/novel-coronavirus-2019/ advice-for-public/q-a-coronaviruses?gclid=CjwKCAjwtqj2BRBYEiwAqfzur6zr-xgyf8-Aqxc823KuVvl50XvV24iiV2AIDeXYbalvBn8JTTxoUxoCkxsQAvD_BwE

30. Dengue. 2019 [Internet]. Georgia, United States: Centers for Disease Control and Prevention; 2019 [accessed: June 27 2020]. Available at: https://www.cdc.gov/dengue/es/symptoms/index.html
31. Dengue: información general [Internet]. Washington, D.C.: Organización Panamericana de la Salud [accessed: June 27 2020]. Available at: https:// www.paho.org/hq/index.php?option=com_content and view=article and id=4493:2010-informacion-general-dengue and Itemid=40232 and lang=es

32. Planificación de la movilización y comunicación social para la prevención y control del Dengue. 2004 [Internet]. Geneva, Switzerland: World Health Organization; 2004 [accessed: June 20, 2020]. Available at: https:// www.who.int/tdr/publications/documents/planificacion_dengue.pdf

33. Sistema Nacional de Vigilancia Epidemiológica. 2020 [Internet]. Mexico City, Mexico: Gobierno de México [accessed: June 20, de 2020]. Available at: https://www.gob.mx/salud/acciones-y-programas/sistema-nacional-de-vigilancia-epidemiologica

34. Diario Oficial de la Federación. Norma Oficial Mexicana NOM-017SSA2-2012, para la vigilancia epidemiológica. 2013 [Internet]. Mexico City, Mexico: Gobierno de México [accessed: June 19, 2020]. Available at: http:// dof.gob.mx/nota_detalle.php?codigo=5288225 and fecha=19/02/2013

35. Yan G, Lee CK, Lam LTM, Yan B, Chua YX, Lim AYN, et al. Covert COVID-19 and false-positive dengue serology in Singapore. Lancet Infect Dis. 2020;20(5):536

36. Joob B, Wiwanitkit V. Hemorrhagic problem among the patients with COVID-19: Clinical summary of 41 Thai infected patients. Clin Appl Thromb Hemost. 2020;26. https://doi.org/10.1177/1076029620918308

37. Joob B, Wiwanitkit V. COVID-19 can present with a rash and be mistaken for Dengue. J Am Acad Dermatol. 2020;83(5):e177.

38. Joob B, Wiwanitkit V. Arthralgia as an initial presentation of COVID-19: observation. Rheumatol Int. 2020;40:823. 